\title{
The Future of Resource Development in the Southern Highlands
}

\section{Chris Warrilow}

\section{The need for contact and communication}

During my 44 years in Papua New Guinea, and especially during the last decade, I have often said that the key to success in dealing with rural people involves contact, contact, and more contact. The government in Papua New Guinea has lost contact with its rural people. In resource-rich areas the vacuum has, to a large extent, been filled by resource developers through their community affairs staff.

One of the greatest assets of the latter days of the Australian administration, retained briefly after independence, was the Department of Information and Extension Services. Using its network of rural workers (kiap, didiman, doktaboi, school teacher, etc.) the government was able to widely disseminate information and conduct activities in the rural areas.

After all the lessons that could have been learnt - but were not — it annoyed me to read, for example, press reports, in early 2003, of Kagua people travelling to Lae in order to press claims of ownership to land upon which one of InterOil's exploration bores was to be drilled. The company hyped up the 'prospect' in the press, which got people from Kerema to Mendi excited as yet again a company, trying to mine the stock exchange floors in Calgary or Sydney, ${ }^{1}$ created unrealistic expectations amongst those in whose province some speculative exploration work was to take place. A few days later another report stated that Baimuru people had called for a mass meeting of 'landowners' to press their claims to the same 'new oil field'. The unsuccessful bore was drilled nearer to Wabo than Baimuru and certainly a long way from Kagua. But lack of meaningful contact and communication by both government and company left two groups of people, living over 100 kilometres apart, in a state of confusion and high expectation. Had there been an unlikely discovery the scene was already set for chaos.

Unrealistic expectations are often raised by both the press and some companies. The press overuses the words 'huge' and 'rich' when reporting, whilst some explorers like to 'talk up' their shares. This leads to inflated demands from members of the landowning clans. Even when a prospect matures to a discovery and from a discovery to a project, it is not necessarily huge or rich. Hides, for instance, with its 7 trillion cubic feet (tcf) of proven reserves, is small in comparison to the Australian Northwest Shelf or recent discoveries in West 
Papua's 'Bird's Head' region where discoveries of 15 tcf to 30 tcf have been made.

\section{Leadership qualities}

Joe Kanekane compares MPs who have represented SHP as its regional/provincial electorate member. He spoke of Ron Neville, SHP's first member (MHA) and of later representatives and their increasingly parochial attitudes (see Kanekane, this volume). This has been particularly evident in the feud between supporters of Dick Mune and Anderson Agiru (the Nipa and the Huli) (see Haley, this volume).

Neville was a former kiap who had served in various parts of Papua New Guinea before becoming a businessman and politician. He had 'opened up' Tari, been OIC at Erave and subsequently set up business in both the latter and Mendi. His first term in the House of Assembly was as regional member for the Western Papua electorate which included the present Western, Gulf and Southern Highlands provinces and half of the Central Province. He thus had a broad view and no 'tribal' loyalties, with the accompanying baggage of wantokism and its inherent obligations.

What SHP needs is a true nationalist as its provincial member governor, who can set an example to the open members and inspire civic and national pride pride of the kind evoked at rugby matches when the Kumuls meet a foreign opponent. Even so, any elected governor will most likely still have two thirds of the province 'against' him - two of the three divisions of west (Huli-Duna), central (Mendi-Nipa), and east (Pangia-Ialibu-Kagua). A true nationalist from a minority area (Erave or Kutubu) could possibly provide the stability needed though we have not seen this to date. The present situation is likely to exacerbate continued demands for a split to create a new (Hela) province, for which the current government has indicated its sympathy.

It is the negative aspects of developments in SHP which have dominated news reports and discussion. The province has its positive aspects that need to be identified and built upon. One positive element is the people themselves. A huge majority (in fact near unanimity in the case of women and children) want the re-establishment of law and order, and the return of services that will bring about. This in turn will bring back the goods and services to those who can afford them, and the means to afford them. More importantly it will enable the next generation to obtain the education so essential if the SHP is to progress to a brighter future.

With law and order established by a strong, competent, honest and disciplined police force, supported by a functioning court system and CIS which keeps convicted thieves, thugs, murderers and rapists behind bars, we might be able to re-establish an effective public service capable of implementing district 
administration. Only then will sustainable postal and communications services, banks, trade stores, and so on reopen, and schools, hospitals and aid posts be staffed again and the goods and supplies required to run and maintain them start flowing again. The limited surplus agriculture and cash crops which are produced may then find a market.

Before building up local institutions which can be run in a sustainable way there are state matters to be attended to by the national government. The SHP has been at the mercy of thieving, gun-running gangsters. The national government must use whatever force is necessary to restore its authority and do it in a way that will see its authority respected and therefore accepted. After that is achieved there can be devolution of powers and capacity-building of local institutions (such as village courts) which can run matters in a more appropriate fashion, taking into consideration traditional norms and values.

In light of the many years of increasing anarchy, measures to achieve the above may, initially, have to be somewhat draconian (at least that is the perception of some Australians). But it is essential that police be handpicked for such an operation and have strong, disciplined leadership.

Political 'leaders' (I prefer to call them the people's elected representatives and law makers) need to be less hands-on and leave the day-to-day administration of the SHP (enforcing laws, implementing policy, and providing services) to a strengthened, competent public service, recruited for the most part from outside the province.

Much has been said about the law and order situation. We have, for example, been told about the blatant stealing and destruction of public property in full view of the Tari police station (see Walters, this volume). Such petty crime seems to go unchecked. Some speakers exhort us to not look back but to look to the future. I believe that we must look back to some extent. How can we expect police to act to deter, arrest, and prosecute petty offenders when so many 'white collar' criminals go so blatantly free?

\section{Resources and the breakdown of law and order}

Elsewhere in this volume, Goldman and Bragge examine possible solutions for the problems they have identified, especially in the context of Huli tradition. However, I do not believe that it is entirely possible to achieve acculturation in a rapidly changing society, thrust into the modern world of resource extraction.

Whereas the 'general' law and order problems resulted in, for example, Oil Search Ltd. (OSL) changing its staff rotation travel arrangements, it was land and royalty issues which resulted in Chevron's many ongoing trials and tribulations at Kutubu/Gobe over the years. OSL felt it had to abandon Tari airstrip (a few road kilometres from its Hides project) and instead, initially, used Hagen airport, from whence it flew its staff by helicopter to and from Hides 
(Moro airstrip is now used). This is an additional cost to what is a marginal project. Chevron, because of the fierce land disputes which seriously delayed development of the Gobe oilfields, had to contend with assaults on its staff, hostage taking, and even aircraft hijacking. So far as I know, few arrests were made and fewer still prosecutions launched. Chevron usually did not seek police intervention when it experienced similar woes later in the life of both Gobe and Kutubu.

Chevron's 'lead and manage, not rule' approach does not seem to have worked. Indeed it was not only physical violence that Chevron quietly tolerated, they also capitulated to verbal threats. Several times, as operator, Chevron has closed down operations because of such threats. They have not only suffered at the hands of 'landowners'; in 2002 the Moro camp was 'shot up' by angry police. Incidents such as this are not conducive to investor confidence. Chevron boasts of its 'landowner' management successes as much as it does of its environmental friendliness. It claims that oil production has never been interrupted because of 'landowner hostilities'. This is not quite true. Oil exports have never been interrupted, but production has been affected because of threats by a few so-called spokesmen of the people to forcibly close the valve at one or more of the pipeline valve stations. However, because Chevron has 600,000 barrels of oil in tanks at Kutubu, another 600,000 barrels in the pipeline itself, and a couple of hundred thousand barrels stored at the Gobe production facility, there has been enough oil to ensure that all export tankers have sailed with a full cargo. By the time the next tanker has tied up to the Kumul offshore loading facility, the dispute has been settled and the threats withdrawn.

\section{The future of petroleum development in the Southern Highlands}

It is well known that the proven Hides gas reserves are sufficient to support a major gas export project. BP pursued the liquid natural gas (LNG) option and before the Southeast Asian crisis of the late 1990s had carried out a number of studies which suggested the preferred option of a pipeline to the north coast, to an export loading facility onshore near Wewak. It then left Papua New Guinea.

Chevron took over as operator of the proposed project and pursued the gas-to-Queensland (GTQ) option. Chevron was not a party to the Hides project, but had realised that its gas reserves in the Kutubu and Gobe fields were insufficient to sustain delivery of the amounts required in the timeframe (30 plus years) to make the proposal economically feasible.

Export of LNG would most likely be more profitable than GTQ, but there is sufficient gas for both projects to go ahead, and the latter seems more likely to proceed in the short term. If GTQ does proceed, it will give Papua New Guinea good returns, especially from the liquids that would be stripped from the gas 
to be sold to the domestic LNG market and exported separately. Also, the infrastructure that would have to be put in place would put Papua New Guinea closer to being able to pursue domestic utilisation of its gas reserves. At the top of Papua New Guinea's 'wish list' is a pipeline to Port Moresby for power generation.

However, to maximise recovery from the fields they operate and presently have interests in, Chevron would have to produce ('blow down') the gas, either by flaring or exporting (they currently reinject the gas). Flaring is perceived to be not environmentally friendly, and in any case would be a waste of Papua New Guinea's resources. But is gas in the ground, at the expense of tens of millions of barrels of oil also left in the ground, of any benefit to Papua New Guinea in the light of its ongoing financial difficulties? A decision, if required in a few years time on these options, will be difficult for the government and the licensees, but the green-sensitive Chevron will no longer be part of the decision making.

The potential market for gas in Queensland was not initially realised by Chevron. Just as Kutubu and Gobe oil was discovered by others, so was the GTQ option first explored by another company, IPC, which had discovered a large gas reserve (Pandora) in the Gulf of Papua in the 1980s.

Of major concern to would-be purchasers of GTQ must be security and continuity of supply. Unlike coffee, tea, cocoa, copra, timber and even oil, gas supplies have to be guaranteed by the one supplier. There is always an oil tanker on the high seas with a cargo which may be diverted for the right price, at any time, to an alternative port where demand is greatest. In any case, countries and companies usually have relatively large reserves of oil stored to meet most short-term shortfalls in deliveries. Gas cannot be stored and moved around so freely. (One only has to look at what happened in Victoria in 1998 when gas deliveries ceased due to an explosion and fire at Esso's Longford plant, where gas from the Bass Strait is processed for delivery to the market.)

Meanwhile, however, one may ask, what about oil? The Kutubu fields (Kutubu, Agogo and Hedinia) are being rapidly depleted. Maximum oil production peaked at around 150,000 barrels per day (bblspd) and it is now less than a third of that. Gobe never reached anticipated production of 50,000 bblspd and is currently declining, at perhaps less than 20,000. Moran is now coming up to full production (maybe 30,000 bblspd), some six years after discovery. With perhaps $80,000,000$ barrels of reserves the field will be exhausted in less than ten years.

What is going to replace this production? It seems nothing. There have been no new commercial discoveries and there seems to be no will to explore, with the cost of drilling wells now up to \$US35 million each (the cost of Esso's recent Bakari well — which proved to be a dry hole). Cheaper wells have recently been 
drilled close to existing infrastructure, but even so, such wells seldom come in at less than \$US8 million (the cost of Santos's Bilip, which discovered oil but seems to lack commercial reserves, despite its proximity to the Gobe facility). The main incentive for drilling at present, it seems, is compliance with licence conditions.

The main disincentive to future development is the failure to date of the GTQ project to proceed to front end engineering and design (FEED), due to lack of confidence in securing the required markets in Queensland. The success rate of drilling is about one well in ten being a 'discovery'; but that one well may not be a commercial discovery, especially if it is gas, which is mainly what has been discovered over the ninety years of drilling in Papua New Guinea. The argument thus goes, if we can't sell the gas we already have, why drill for more?

The only possible commercial discovery still undeveloped is that at South East Mananda, on the opposite side of the Hegigio Gorge from the Agogo facility (which also processes the output of Moran). To get oil from Southeast Manada to Agogo will be, to say the least, an engineering challenge.

There is still some potential at Juha and Hides, in so far as the three wells drilled on the former anticline and the four on the latter have yet to establish a liquid contact (that is, reach the lowest depth of the gas, where it sits on either water or oil). There are additional new 'plays' in the existing fields where the sub-thrust zones have yet to be tested by drilling into the footwalls of Hides, Mananda, Hedinia, Gobe and even Kutubu. Such wells would be expensive, despite being close to roads and other infrastructure, and the drilling fraught with the difficulties of penetrating deep down into the fold belt with its many geological faults creating a drilling engineer's nightmare.

Maybe, if the rule of law were re-established and government took back more of the responsibilities of governing and providing for its people, explorers might drill these wells. Perhaps some of the old players, who have tried and left after lack of success, might return to try new ideas and plays. Even so, as witnessed in the time gap between discovery and development at Moran, if there were a new commercial discovery tomorrow, it could well be that production would not commence until after all other oil reserves had been depleted some years earlier.

The province has not revealed any mineral wealth to date and there is currently no hard rock exploration taking place. Mount Kare, in Enga, if developed, would have spin-off benefits for SHP. However, I believe the Canadian operator, Madison Resources, is intent on attracting a buyer to take over its exploration licence.

\section{ENDNOTES}

1 The prospect was named Moose - to promote the sale of shares in North America. 